\title{
Perspectives
}

\section{The Neglected Combination: A Case for Explicit-Inductive Instruction in Teaching Pragmatics in ESL}

Karen Glaser

A substantial part of interlanguage pragmatics (ILP) research has contrasted explicit and implicit teaching designs, generally finding that explicit approachesthose featuring metapragmatic rule provision-are more effective than their implicit counterparts, which are characterized by the absence of metapragmatic information. A second dichotomy used to characterize instructional designs, that of deductive vs. inductive approaches, has received somewhat less attention. Concerned with the sequencing of the instruction rather than the criterion of whether or not to provide rules, this concerns the question of whether to choose (deductive) rules or (inductive) language use as the starting point of the instruction. Although the two dichotomies are interrelated, they are often unjustifiably merged, with the labels deductive and explicit, on the one hand, and inductive and implicit, on the other, being used interchangeably. This article illustrates the reasons for this oversimplification and argues that the resulting focus on the contrast of explicit-deductive and implicit-inductive designs has led to overlooking a third possible constellation: the explicit-inductive framework. Adopting a classroom perspective, the article further attempts to point out the advantages that this neglected combination can have for the teaching and learning of pragmatics in ESL.

Une partie importante de la recherche sur la compétence pragmatique interlangue a contrasté les conceptions didactiques explicites et implicites et a conclue que, de façon générale, les approches explicites, celles qui incluent les règles portant sur la compétence métapragmatique, s'avèrent plus efficaces que les approches implicites qui ne touchent pas cet élément. Une deuxième dichotomie caractérisant les conceptions didactiques, celle-ci reposant sur la comparaison des approches inductives et déductives, a moins fait l'objet d'intérêt. Préoccupée par l'enchainement de l'instruction plutôt que l'explication de règles, cette dichotomie vise le choix entre les règles déductives d'une part ou l'emploi inductif de la langue d'autre part comme point de départ de l'enseignement. Quoique ces deux dichotomies soient liées, elles sont souvent fusionnées à tort et les étiquettes "déductive et explicite » et «inductive et implicite» sont utilisées de manière interchangeable. Cet article explique les raisons derrière cette simplification excessive et soutient que la concentration axée sur le contraste entre une conception explicite-déductive 
et une conception implicite-inductive qui en découle a éclipsé une troisième possibilité : un cadre explicit-inductif. Adoptant une perspective de la salle de classe, l'on présente les avantages que cette combinaison négligée peut représenter pour l'enseignement et l'apprentissage de la compétence pragmatique en ALS.

Research of the past three decades has shown almost unanimously that the teaching of pragmatic skills to language learners is not only feasible (AlcónSoler, 2008; Kasper, 1997, 2001; Rose, 2005) and desirable (Bardovi-Harlig, 2001; Ishihara \& Cohen, 2010), but also more effective than mere exposure to the target language (Bouton 1994a, 1994b; Félix-Brasdefer, 2006; Jeon \& Kaya, 2006). To analyze the specific conditions under which pragmatic instruction is especially beneficial, quite a number of quasi-experimental studies have focused on the comparison of explicit versus implicit teaching designs. As Norris and Ortega (2000) point out, the difference between these two approaches consists in whether the learners are provided with rule explanations at some point during the instruction. With regard to the specific case of interlanguage pragmatics, this concerns the question of whether or not explicit metapragmatic information is provided to help the learners perceive and understand the target features more easily (Rose, 2005). If it is provided, the design is referred to as explicit. If the instruction does not feature any metapragmatic rule provision, the design counts as implicit. Typically, the effectiveness of these two designs has been investigated by means of quasi-experimental studies that contrast an explicitly taught and an implicitly taught learner group (and sometimes a control group that is not instructed with regard to the respective pragmatic features). Although in some studies both learner groups were equally successful (Martínez-Flor, 2004, 2006; Martínez-Flor \& Alcón-Soler, 2007) or varied in their successfulness depending on test type (Duan \& Wannaruk, 2010; Tateyama, 2001), the large majority of interventional pragmatics studies have come to the conclusion that explicit teaching is more effective than implicit instruction. This research includes work on the production of speech acts such as requests (Alcón-Soler, 2005; Gu, 2011; Takimoto, 2006), refusals (Farrokhi \& Atashian, 2012), or expressions of gratitude (Ghobadi \& Fahim, 2009); on pragmatic routines (Tateyama, Kasper, Mui, Tay, \& Thananart, 1997); on active listening behaviour (Cutrone, 2013); and on sociopragmatic awareness (Takahashi, 2010). All of these studies conclude that learners profit from being given explicit metapragmatic information in their development of pragmatic competence.

Given this effectiveness of metapragmatic rule provision, teachers might ask themselves - and rightly so - when and how to best provide this information in the course of their pragmatics lessons or units. Is it advisable to give the rules first and subsequently engage the students in the application of these rules through exercises and activities? Or is it better to confront the students with language material first and provide the rules later, possibly as some 
sort of a summary of the previous activities? These considerations concern a second dichotomy in language teaching methodology - in fact, in teaching methodology in general - namely that of inductive versus deductive teaching designs. Although some ILP scholars make reference to this dichotomy in their teaching suggestions (e.g., Eslami \& Eslami-Rasekh, 2008; EslamiRasekh, 2005; Martínez-Flor, 2008), it has received far less attention than the explicit-implicit distinction, especially in terms of empirical research. This article will introduce this lesser known dichotomy and subsequently point out how it relates to the explicit-implicit distinction, how these two dimensions are often confounded, and how we and our learners can profit from incorporating the largely neglected explicit-inductive combination into our teaching.

\section{When and How to Provide the Rules: The Inductive-Deductive Dichotomy}

As Decoo (1996) explains, deductive approaches are those that take as their departure point the provision of rules. With regard to the teaching of pragmatics, this means that a teaching sequence starts by equipping the students with metapragmatic information. For instance, we tell our students that when native speakers of English want to disagree politely, they use extensive pausing and hesitation (Félix-Brasdefer, 2009; Houck \& Fujii, 2006; Pomerantz, 1984; Santamaría-García, 2011), they often give reasons and explanations for their disagreement (Cheng \& Tsui, 2009; García, 1989; Kuo, 1994; Locher, 2004; Yates, 2010), and they have been observed to employ requests for clarification (Bardovi-Harlig \& Salsbury, 2004; Burdine, 2001; Lawson, 2009). After this imparting of "rules" to the learners, the deductive approach continues with exercises and activities to practice these rules.

Inductive approaches, on the other hand, proceed from "real language use" (Decoo, 1996, p. 96), that is, from concrete examples to more general patterns. The learners are first introduced to language material that contains the linguistic features to be acquired without being given any explicit rules, at least not initially. Rather, they are encouraged to engage in language use and, possibly, language discovery activities. For example, we can provide the learners with concrete instances of native speaker conversational behaviour, perhaps through transcribed conversations (Huth, 2010), sequences from films (Fernández-Guerra \& Martínez-Flor, 2003; Rose, 1997, 2001) or TV series (Alcón-Soler, 2005; Martínez-Flor \& Usó-Juan, 2010; Quaglio, 2009), or, if we are very fortunate, audio or even video recordings of authentic interactions. In addition, we can encourage our students to produce the target language functions themselves to try out their own skills and strategies (Huth, 2007; Kondo, 2008). This mode of instruction is assumed to mirror first language acquisition to some extent and is thus frequently associated with language $a c$ quisition, while deductive teaching is often said to be on a par with language learning (Decoo, 1996). 
As we have seen from this brief explanation of the terms, the deductiveinductive dichotomy is concerned with the sequencing, or rather, the starting point of the instruction: What will our learners encounter first-the rules (deductive) or the language (inductive)? This distinction is thus different in focus from the explicit-implicit opposition, although they are related in the sense that any deductive design is by definition an explicit one as it requires the provision of rules. What is, however, not automatically given is the equation of inductive with implicit. Yet the two oppositions have often been confounded, resulting in the equation of deductive with explicit on the one hand, and inductive with implicit on the other hand. This might result from the fact that any implicit design is automatically inductive in nature as it does not feature the provision of rules and thus cannot be explicit. What is, however, missing from this simplification is a teaching design that starts out inductively by providing language examples first and later addresses the underlying rules explicitly, namely, an explicit-inductive approach.

DeKeyser's (2003) paper on different learning types is helpful in shedding light on the relationship between the two dichotomies. Even though he discusses learning rather than teaching styles, his suggestion to view the two oppositions as a matrix rather than two separate continua (which are then easily confused) also applies to teaching designs. In an adaptation of his figure (see Figure 1), we can depict the connections between the explicit-implicit and the deductive-inductive oppositions.

\begin{tabular}{|c|c|c|}
\hline $\begin{array}{r}\text { rules } \\
\text { starting } \\
\text { point? }\end{array}$ & $\begin{array}{l}\text { explicit } \\
\text { (rules) }\end{array}$ & $\begin{array}{l}\text { implicit } \\
\text { (no rules) }\end{array}$ \\
\hline $\begin{array}{l}\text { deductive } \\
\text { (rules first) }\end{array}$ & explicit-deductive & $n / a^{1}$ \\
\hline $\begin{array}{l}\text { inductive } \\
\text { (language first) }\end{array}$ & explicit-inductive & implicit-inductive \\
\hline
\end{tabular}

Figure 1: The relationship of the explicit/implicit and inductive/deductive dichotomies (adapted from DeKeyser, 2003, $p$. 314)

As we can see, one cell-the implicit-deductive combination-is empty, for the reason stated above: a deductive design proceeds from the rule provision, an element that is, by definition, absent from implicit approaches. It is perhaps the absence of this combination and the resulting imbalance in the matrix that has given rise to the widespread notion that the two dichotomies are simply different names for the same phenomena. Vague (though not necessarily incorrect) formulations in research papers contrasting explicit-deductive and implicit-inductive conditions in ILP research (e.g., Rose \& Ng, 2001; 
Trosborg \& Shaw, 1998) and in articles reviewing the respective findings (e.g., Martínez-Flor, 2004; Rose, 2005; Trosborg, 2003; Trosborg \& Shaw, 2008) may have reinforced the notion that the two dichotomies are merely different labels for the same distinction. Regrettably, this simplification occurs at the expense of one cell, namely the combination of explicit rule provision with an inductive teaching sequence, that is, the explicit-inductive approach.

This oversight is problematic not only from a theoretical-heuristic perspective, but also-or even more so-with regard to the pedagogical reality in the foreign language classroom. If we are only aware of explicit-deductive and implicit-inductive approaches, and if we know that implicit instruction is less effective than explicit instruction, we are automatically left with lesson plans that are deductive in nature. What this amounts to is foreign language instruction that proceeds from a teacher-centred rule provision, presenting the learners rather invariably with abstract and prescriptive rule information and depriving them of opportunities of discovering the language actively for themselves - either on their own or through meaningful peer interaction and social learning (Ohta, 1995, 2005; Vygotsky, 1978). But this does not have to be the case if we also make room for the explicit-inductive combination in the classroom, as shown below.

\section{What the Research Says: Effectiveness of Explicit-Inductive Instruction}

Unfortunately, research contrasting explicit-deductive and explicit-inductive designs is largely nonexistent in interlanguage pragmatics studies. The only attempts at contrasting inductive and deductive designs in pragmatics teaching of which I am aware have been undertaken by Rose and $\mathrm{Ng}$ (2001), Trosborg and Shaw (2008), and Takimoto (2008). Regrettably, all of these contrast explicit-deductive and implicit-inductive designs, ${ }^{2}$ making it virtually impossible to say which of the two dichotomies has given rise to the observed results. In the wider area of SLA research, however, studies investigating inductive and deductive instruction have found that inductively taught learners outperformed their deductively taught peers if both designs featured explicit rule provision. In other words, explicit-inductive designs were more beneficial than explicit-deductive ones. This has been shown for various grammar structures in French (Haight, Herron, \& Cole, 2007; Vogel \& Engelhard, 2011; Vogel, Herron, Cole, \& York, 2011) and for the contrasts between connaitre/savoir in French as well as ser/estar and saber/conocer in Spanish (Shaffer, 1989). If, on the other hand, the inductively taught students were not provided with rules (i.e., if they were taught according to the implicitinductive approach), they were less successful than the (explicit-)deductive group, as documented by Erlam $(2003,2005)$ for direct object pronouns in French, by Robinson (1996) for subject-verb position and cleft sentences with 
adverbials of place in English, by Rosa and O'Neill (1999) for the present and past unreal conditionals in Spanish, and by Seliger (1975) for the position of noun modifiers in English as a foreign language. This suggests that, although overall the explicit-implicit distinction appears to be the dominant factor and learners profit most from being provided the rules, within the explicit paradigm inductive instruction is more effective than deductive instruction. That is, the learners profit most from discovering the rules in the language material as opposed to being given them from the start. In sum, this means that an explicit-inductive approach is most beneficial for the learners.

One reason for this superiority of inductive teaching might lie in the element of guided discovery (Crandall \& Basturkmen, 2004; Sharwood-Smith, 1988; Tomlinson, 1994), which is an integral part of many inductive designs. ${ }^{3}$ This means that the instruction features elements and activities during which the learners actively engage in analyzing and discovering the language themselves, guided and helped - but not dominated-by the teacher. Such active learner participation in the discovery of "regularities and relationships" has been identified as a decisive factor in the learning process (Bruner, 1961, p. 24). Similarly, Hammerly (1975) found that "'learning by discovery' is better retained" (p. 18). As Herron and Tomasello (1992) point out, "passivity on the part of the student runs contrary to findings of cognitive psychologists and researchers who stress that language learners need to be actively engaged in their learning" (p. 709). With regard to the teaching of pragmatics, Ishihara and Cohen (2010) concede that the findings are "inconclusive at this point" (p. 117), but at the same time they suggest that inductive instruction is "generally believed to promote higher-order thinking and may be more effective than a deductive approach" (p. 116). Accordingly, lesson plans that allow for an inductive discovery process while fulfilling the condition of explicit rule provision seem very promising for pragmatics instruction. The following example of teaching polite disagreements to learners of English might serve as an illustration of how such an explicit-inductive design can be put into practice in the ESL/EFL classroom.

\section{Using an Explicit-Inductive Approach in Pragmatics Instruc- tion: The Example of Teaching Polite Disagreements in ESL}

One way of starting a pragmatics unit on disagreements (in fact, on any speech act) could be to ask the students to role-play a few disagreement scenarios in the L2, which are videotaped (with student consent) for later use. For example, the learners could be asked to disagree with a professor on the time of an appointment or with a friend on the beauty of a couch in a shop window (Walkinshaw, 2007). In so doing, we instructors not only compile an invaluable source of language material to be used later for auto-input ${ }^{4}$ (House, 1996; Schmidt \& Frota, 1986; Sharwood-Smith, 1988) and discovery 
activities, but we also give students the opportunity to engage in real language use.

Following the role-play activity, the students could be shown a sequence from a TV series or a film containing polite disagreement to provide some authentic audio-visual input. It is recommended to introduce the show or film, the setting, and the characters to the students to provide as much context information as possible before playing the scenes. ${ }^{5}$ Depending on the proficiency level of the learners, tapescripts can be useful. Again aiming for as much contextualization as possible, we might want to discuss the scenes from a content perspective first and then go on to talk about what happened between the speakers and the effect that the disagreement expression had on the hearer. This can be followed by an activity in which the learners find the disagreement features and strategies that the speakers employ in the utterances (tapescripts are very helpful here, even with advanced learners). These are subsequently collected on the blackboard, or on a transparency, a PowerPoint slide, etc. If there is enough time, the students can be asked to share their own experiences with disagreement situations, in either their L1 or L2, thus making the classroom discourse directly meaningful to their own personal reality.

In an ESL environment, this can be followed up with a students-as-ethnographers activity (Bardovi-Harlig, 1996; Roberts, Byram, Barro, Jordan, \& Street, 2001; Tanaka, 1997) in which the learners collect their own small corpus of disagreements they encounter in real life. If this is not possible (most likely in EFL environments), we can bring authentic examples into the classroom by sharing the results from a corpus search, such as the spoken section of the Corpus of Contemporary American English (COCA; Davies, 2008-), or maybe even have the students conduct their own corpus exploration in the computer lab.

With each of the previously mentioned activities, the main criteria of inductive teaching are fulfilled: we have provided the learners with opportunities of language use first, through production activities, authentic language material, and concrete examples. We have chosen as the starting point of our instruction the language itself, rather than the rules that govern that language. We have given our students the chance to encounter, to experience, and to try out the language.

But knowing that learners profit from explicit rule provision, we do not want to leave it at that. We not only want our students to understand the examples, but we also want them to be able to see and derive the general patterns behind them. We want to generalize and to point out strategies and expressions to the learners so that they have a toolkit available for their own language use. Expressing it in the terms of Schmidt's $(1993,1995,2001)$ Noticing Hypothesis, we want to point their attention to the underlying patterns so that intake and learning can take place: 
What must be attended to is not input in general, but whatever features of the input play a role in the system to be learned. For the learning of pragmatics in a second language, attention to linguistics forms, functional meanings, and the relevant contextual features is required. (Schmidt, 1993, p. 35)

To do so in our classroom example, we can now return to the disagreement utterances we collected earlier on the blackboard, transparencies, or PowerPoint slides, and through the corpus work, and we can encourage our students to look for more general patterns behind them, eventually arriving at the same rule provision mentioned above for the deductive design (e.g., pausing and hesitation, explanations, clarification requests). If we fear that this relatively free and unassisted pattern-recognition task might be too challenging for our learners, we can provide scaffolding by visual enhancement strategies that highlight the features in question (Izumi, 2002; Sharwood-Smith, 1993; Takimoto, 2009), such as using different colours or fonts or grouping utterances with similar features for easier recognition.

We can now play the role-play recordings (or provide them in an anonymized, transcribed form if the students are uncomfortable with having their video shown) and guide the students' attention toward recognizing the absence of the strategies and mitigational devices just discovered for native speaker disagreement and, if applicable, make them aware of features and patterns typically associated with nonnative speaker disagreement, such as lack of initial mitigation (Takahashi \& Beebe, 1993), the bare no (Bell, 1998), or the overuse of I'm sorry (Kreutel, 2007). In this way, we are also catering to the more analytical learners who profit most from working with patterns and rules. But instead of merely presenting those rules in isolation first (as would be the case in a deductive design), we have embedded these in meaningful contexts and language use. In terms of the dichotomies introduced above, we have combined both an inductive and an explicit framework - in starting out with authentic language use, we have used an inductive design, but in deciding to subsequently deliver metapragmatic information, we have allowed our learners to profit from explicit instruction as well.

\section{Why It's Worth It}

In talking to language teachers, I often cannot help but notice a certain reluctance on their part to implement inductive units in their lessons, preferring explicit-deductive procedures instead. The reasons for this choice usually fall into one of three categories (or, often, a combination of them). The first, and probably most justified, concerns the additional time needed for preparation. Yes, it is time-consuming to create language discovery activities, especially when it comes to finding authentic materials. Not every teacher has the time to comb through hours of DVD material just to find one or two instances of 
disagreement (e.g., requests, compliments, thanks) that are suitable for their lesson the next day. Nor do they always have the time and energy to concoct new interactive and engaging inductive classroom activities, let alone to fabricate all the slips of paper, cards, and costumes they would need to put them into practice. Yet I am convinced that a change in perspective on teaching styles will also entail a change in how we approach our lesson planning and the collection of teaching materials. We might start to develop a new view of the language resources we have available around us and scan them for their suitability for our pragmatics teaching as we encounter them-rather than starting a frantic search for suitable materials the night before our lesson is due the next morning. We might start to see the conversations and interactions taking place around us every day as a resource of teaching activities and opportunities for our students to engage in actual language use and simulations of real-life encounters, thus hopefully finding it less and less difficult and taxing to come up with inductive teaching activities.

The second reason teachers cite is the fear of relinquishing control in the classroom (although it is never put quite like that). As opposed to the more teacher-centred deductive approach, where the instructor controls the sequencing and timing of the activities, inductive activities can take a lot of unexpected turns, and it is admittedly not always easy to steer the discovery process in the direction in which we want it to go. Sometimes, instead of the 15 minutes we had planned for a certain activity, it takes the students 45 , and we might just as well forget about all of the other things we wanted to cover in that lesson. But is it really so problematic if our students are interested in aspects of the materials other than the ones we preselected for them? Should it not be encouraging for us if our students approach the materials in a way that is significant to them? Language learning can also take place "through the back door"; that is, through vocabulary and comprehension questions or student discussions that we had not planned initially. In fact, more often than not it is the teachers who consider these detours the back door, when actually they have succeeded in opening the front door wide for their students to explore the language in a way that is meaningful to them. We will find it was worth all the detours when our students' faces say, "I have discovered for myself how this works, how people in the foreign language do these things that I've never really noticed or thought about before."

The third caveat that instructors have is their doubting that the inductive approach will work with their learners. It is all very well in theory, they say, but my students would never do this, they would not know what to do, they would not participate. And it is true that with inductive activities we need to be specifically careful with the instructions we give in the classroom so that our learners know exactly what we would like them to do and how much freedom they have. And maybe the first or second time we implement inductive approaches things go awry and we notice the shortcomings in our materials and instructions. But I would like to encourage all the teachers who shy 
away from adopting inductive procedures in their classrooms to start having more confidence in their learners and to trust their students' abilities to carry out open, exploratory, and interactive activities, even at lower proficiency levels. Maybe the students will find this strange at first, especially if they are not used to this teaching style at all. But students generally enjoy being given the chance to approach the foreign language on their own terms and at their own pace, and to truly discover, experience, and feel this medium of communication based on what they perceive as meaningful. By combining the inductive and the explicit frameworks in our teaching, we provide them with opportunities to encounter the language through embodiment (inductive) as well as cognitive understanding (explicit). In short, we present our learners with the best of two worlds.

\section{Notes}

${ }^{1}$ DeKeyser's table lists parameter setting in Universal Grammar here. This is, however, a category that is very specific to the internal processes of learning (which is the focus of DeKeyser's article) and hence does not apply to teaching designs.

${ }^{2}$ Although Takimoto (2008) labels the inductive condition as explicit, a closer look at the pragmatic intervention shows that the students are not provided with explicit rules, making the condition implicit-inductive rather than explicit-inductive.

${ }^{3}$ Decoo (1996) also discusses inductive-explicit designs that do not feature guided discovery.

4 This hypothesis suggests that "learners' confrontation with their own output ... is a significant part of their input" (House, 1996, p. 247). Playback of the students' own speech productions can be combined with teacher feedback and/or student self-assessments and provide the learners with the chance to think of and provide more target-like alternative realizations.

${ }^{5}$ The students could also be asked to watch the complete movie or episode at home as a preparatory out-of-class assignment. This might be especially relevant for integrated skills courses that also focus on listening skills and vocabulary acquisition.

\section{The Author}

Karen Glaser is a PhD candidate in English Linguistics at Leuphana University Lüneburg and an EFL instructor at Chemnitz University of Technology, Germany. Her research interests include interlanguage pragmatics, SLA, and language teaching methodology. Her teaching foci in the EFL classroom include pragmatics, intercultural awareness, and English for Academic Purposes.

\section{References}

Alcón-Soler, E. (2005). Does instruction work for learning pragmatics in the EFL context? System, 33(3), 417-435.

Alcón-Soler, E. (Ed.). (2008). Learning how to request in an instructed language learning context. Bern, Switzerland: Peter Lang.

Bardovi-Harlig, K. (1996). Pragmatics and language teaching: Bringing pragmatics and pedagogy together. In L. F. Bouton (Ed.), Pragmatics and language learning (Vol. 7, pp. 21-39). UrbanaChampaign, IL: University of Illinois.

Bardovi-Harlig, K. (2001). Evaluating the empirical evidence: Grounds for instruction in pragmatics? In K. R. Rose \& G. Kasper (Eds.), Pragmatics in language teaching (pp. 13-32). New York, NY: Cambridge University Press.

Bardovi-Harlig, K., \& Salsbury, T. (2004). The organization of turns in the disagreements of L2 learners: A longitudinal perspective. In D. Boxer \& A. D. Cohen (Eds.), Studying speaking to inform second language learning (pp. 199-227). Clevedon, UK: Multilingual Matters. 
Bell, N. (1998). Politeness in the speech of Korean ESL learners. Working Papers in Educational Linguistics, 14(1), 25-47.

Bouton, L. F. (1994a). Can NNS skill in interpreting implicature in American English be improved through explicit instruction? A pilot study. In L. F. Bouton \& Y. Kachru (Eds.), Pragmatics and language learning (Vol. 5, pp. 89-109). Urbana-Champaign, IL: University of Illinois.

Bouton, L. F. (1994b). Conversational implicature in a second language: Learned slowly when not deliberately taught. Journal of Pragmatics, 22(2), 157-167.

Bruner, J. S. (1961). The act of discovery. Harvard Educational Review, 31, 21-32.

Burdine, S. (2001). The lexical phrase as pedagogical tool: Teaching disagreement strategies in ESL. In R. C. Simpson \& J. M. Swales (Eds.), Corpus linguistics in North America: Selections from the 1999 symposium (pp. 195-210). Ann Arbor, MI: University of Michigan Press.

Cheng, W., \& Tsui, A. B. M. (2009). "ahh ((laugh)) well there is no comparison between the two I think": How do Hong Kong Chinese and native speakers of English disagree with each other? Journal of Pragmatics, 41(11), 2365-2380.

Crandall, E., \& Basturkmen, H. (2004). Evaluating pragmatics-focused materials. ELT Journal, $58(1), 38-49$.

Cutrone, P. (2013). Assessing pragmatic competence in the Japanese EFL context: Towards the learning of listener responses. Newcastle, UK: Cambridge Scholars Publishing.

Davies, M. (2008-). The Corpus of Contemporary American English (COCA): 450 million words, 1990present. Retrieved from http://corpus.byu.edu/coca/

Decoo, W. (1996). The induction-deduction opposition: Ambiguities and complexities of the didactic reality. International Review of Applied Linguistics, 34(2), 95-118.

DeKeyser, R. M. (2003). Implicit and explicit learning. In C. J. Doughty \& M. Long (Eds.), The handbook of second language acquisition (pp. 313-348). Malden, MA: Blackwell.

Duan, L., \& Wannaruk, A. (2010). The effects of explicit and implicit instruction in English refusals. Chinese Journal of Applied Linguistics, 33(3), 93-109.

Erlam, R. (2003). The effects of deductive and inductive instruction on the acquisition of direct object pronouns in French as a second language. Modern Language Journal, 87(2), 242-260.

Erlam, R. (2005). Language aptitude and its relationship to instructional effectiveness in second language acquisition. Language Teaching Research, 9(2), 147-171.

Eslami, Z. R., \& Eslami-Rasekh, A. (2008). Enhancing the pragmatic competence of non-native English-speaking teacher candidates (NNESTCs) in an EFL context. In E. Alcón-Soler \& A. Martínez-Flor (Eds.), Investigating pragmatics in foreign language learning, teaching and testing (pp. 178-197). Bristol, UK: Multilingual Matters.

Eslami-Rasekh, Z. (2005). Raising the pragmatic awareness of language learners. ELT Journal, 59(3), 199-208.

Farrokhi, F., \& Atashian, S. (2012). The role of refusal instruction in pragmatic development. World Journal of Education, 2(4), 85-93.

Félix-Brasdefer, J. C. (2006). Teaching the negotiation of multi-turn speech acts: Using conversation-analytic tools to teach pragmatics in the FL classroom. In K. Bardovi-Harlig, J. C. Félix-Brasdefer, \& A. S. Omar (Eds.), Pragmatics and language learning (Vol. 11, pp. 166197). Honolulu, HI: University of Hawai'i Press.

Félix-Brasdefer, J. C. (2009). Dispreferred responses in interlanguage pragmatics: Refusal sequences in learner-NS interactions. Applied Language Learning, 19(1-2), 1-27.

Fernández-Guerra, A., \& Martínez-Flor, A. (2003). Requests in films and in EFL textbooks: A comparison. Estudios de Lingüística Inglesa Aplicada, 4, 17-34.

García, C. (1989). Disagreeing and requesting by Americans and Venezuelans. Linguistics and Education, 1(3), 299-322.

Ghobadi, A., \& Fahim, M. (2009). The effect of explicit teaching of English "thanking formulas" on Iranian EFL intermediate level students at English language institutes. System, 37(3), 526-537.

$\mathrm{Gu}, \mathrm{X}$.-L. (2011). The effect of explicit and implicit instructions of request strategies. Intercultural Communication Studies, 20(1), 104-123. 
Haight, C. E., Herron, C., \& Cole, S. P. (2007). The effects of deductive and guided inductive instructional approaches on the learning of grammar in the elementary foreign language college classroom. Foreign Language Annals, 40(2), 288-310.

Hammerly, H. (1975). The deduction/induction controversy. Modern Language Journal, 59(1-2), $15-18$

Herron, C., \& Tomasello, M. (1992). Acquiring grammatical structures by guided induction. French Review, 65(5), 708-718.

Houck, N., \& Fujii, S. (2006). Delay as an interactional resource in native speaker-nonnative speaker academic interaction. In K. Bardovi-Harlig, C. Félix-Brasdefer, \& A. S. Omar (Eds.), Pragmatics and language learning (Vol. 11, pp. 29-53). Honolulu, HI: University of Hawai'i Press.

House, J. (1996). Developing pragmatic fluency in English as a foreign language: Routines and metapragmatic awareness. Studies in Second Language Acquisition, 18(2), 225-252.

Huth, T. (2007). Pragmatics revisited: Teaching with natural language data. Die Unterrichtspraxis/ Teaching German, 40(1), 21-33.

Huth, T. (2010). Intercultural competence in conversation: Teaching German requests. Die Unterrichtspraxis/Teaching German, 43(2), 154-166.

Ishihara, N., \& Cohen, A. D. (2010). Teaching and learning pragmatics: Where language and culture meet. Harlow, UK: Pearson Education.

Izumi, S. (2002). Output, input enhancement, and the noticing hypothesis: An experimental study on ESL relativization. Studies in Second Language Acquisition, 24(4), 541-577.

Jeon, E. H., \& Kaya, T. (2006). Effects of L2 instruction on interlanguage pragmatic development: A meta-analysis. In J. M. Norris \& L. Ortega (Eds.), Synthesizing research on language learning and teaching (pp. 165-211). Philadelphia, PA: John Benjamins.

Kasper, G. (1997). Can pragmatic competence be taught? (NFLRC NetWork \#6). Honolulu, HI: University of Hawai'i, Second Language Teaching and Curriculum Center. Retrieved from http://www.nflrc.hawaii.edu/networks/NW06/default.html

Kasper, G. (2001). Classroom research on interlanguage pragmatics. In K. Rose \& G. Kasper (Eds.), Pragmatics in language teaching (pp. 33-60). New York, NY: Cambridge University Press.

Kondo, S. (2008). Effects on pragmatic development through awareness-raising instruction: Refusals by Japanese EFL learners. In E. Alcón-Soler \& A. Martínez-Flor (Eds.), Investigating pragmatics in foreign language learning, teaching and testing (pp. 153-177). Clevedon, UK: Multilingual Matters.

Kreutel, K. (2007). “I'm not agree with you”: ESL learners' expressions of disagreement. TESL-EJ, 11(3), 1-35.

Kuo, S. (1994). Agreement and disagreement strategies in a radio conversation. Research on Language and Social Interaction, 27(2), 95-121.

Lawson, A. J. (2009). From the classroom to the bar-room: Expressions of disagreement by Japanese speakers of English (Unpublished master's thesis). University of Birmingham, United Kingdom..

Locher, M. A. (2004). Power and politeness in action: Disagreements in oral communication. Berlin, Germany: Mouton de Gruyter.

Martínez-Flor, A. (2004). The effect of instruction on the development of pragmatic competence in the English as a foreign language context: A study based on suggestions (Unpublished doctoral dissertation). Universitat Jaume I, Castellón, Spain.

Martínez-Flor, A. (2006). The effectiveness of explicit and implicit treatments on EFL learners' confidence in recognizing appropriate suggestions. In K. Bardovi-Harlig, C. Félix-Brasdefer, \& A. S. Omar (Eds.), Pragmatics and language learning (Vol. 11, pp. 199-225). Honolulu, HI: University of Hawai'i Press.

Martínez-Flor, A. (2008). The effect of an inductive-deductive teaching approach to develop learners' use of request modifiers in the EFL classroom. In E. Alcón-Soler (Ed.), Learning 
how to request in an instructed language learning context (pp. 191-225). Bern, Switzerland: Peter Lang.

Martínez-Flor, A., \& Alcón-Soler, E. (2007). Developing pragmatic awareness of suggestions in the EFL classroom: A focus on instructional effects. Canadian Journal of Applied Linguistics, $10(1), 47-76$.

Martínez-Flor, A., \& Usó-Juan, E. (2010). The teaching of speech acts in second and foreign language instructional contexts. In A. Trosborg (Ed.), Pragmatics across languages and cultures (pp. 423-442). Berlin, Germany: Mouton de Gruyter.

Norris, J. M., \& Ortega, L. (2000). Effectiveness of L2 instruction: A research synthesis and quantitative meta-analysis. Language Learning, 50(3), 417-528.

Ohta, A. S. (1995). Applying sociocultural theory to an analysis of learner discourse: Learnerlearner collaborative interaction in the zone of proximal development. Issues in Applied Linguistics, 6(2), 93-121.

Ohta, A. S. (2005). Interlanguage pragmatics in the zone of proximal development. System, 33(3), 503-517.

Pomerantz, A. (1984). Agreeing and disagreeing with assessments: Some features of preferred/ dispreferred turn shapes. In J. M. Atkinson \& J. Heritage (Eds.), Structures of social action: Studies in conversation analysis (pp. 57-101). Cambridge, UK: Cambridge University Press.

Quaglio, P. (2009). Television dialogue: The sitcom Friends vs. natural conversation. Amsterdam, Netherlands: John Benjamins.

Roberts, C., Byram, M., Barro, A., Jordan, S., \& Street, B. (2001). Language learners as ethnographers. Clevedon, UK: Multilingual Matters.

Robinson, P. (1996). Learning simple and complex second language rules under implicit, incidental, rule-search, and instructed conditions. Studies in Second Language Acquisition, 18(1), 27-67.

Rosa, E., \& O'Neill, M. D. (1999). Explicitness, intake, and the issue of awareness: Another piece to the puzzle. Studies in Second Language Acquisition, 21(4), 511-556.

Rose, K. R. (1997). Pragmatics in the classroom: Theoretical concerns and practical possibilities. In L. F. Bouton (Ed.), Pragmatics and language learning (Vol. 8, pp. 268-295). Urbana-Champaign, IL: University of Illinois.

Rose, K. R. (2001). Compliments and compliment responses in film: Implications for pragmatics research and language teaching. International Review of Applied Linguistics in Language Teaching, 39(4), 309-326.

Rose, K. R. (2005). On the effects of instruction in second language pragmatics. System, 33(3), 385-399.

Rose, K. R., \& Ng, C. K. (2001). Inductive and deductive teaching of compliments and compliment responses. In K. Rose \& G. Kasper (Eds.), Pragmatics in language teaching (pp. 145-170). Cambridge, UK: Cambridge University Press.

Santamaría-García, C. (2011). Bricolage assembling: CL, CA and DA to explore agreement. International Journal of Corpus Linguistics, 16(3), 345-370.

Schmidt, R. (1993). Consciousness, learning, and interlanguage pragmatics. In G. Kasper \& S. Blum-Kulka (Eds.), Interlanguage pragmatics (pp. 21-42). New York, NY: Oxford University Press.

Schmidt, R. (1995). Consciousness and foreign language learning: A tutorial on the role of attention and awareness in learning. In R. Schmidt (Ed.), Attention and awareness in foreign language learning (pp. 1-64). Honolulu, HI: University of Hawai'i Press.

Schmidt, R. (2001). Attention. In P. Robinson (Ed.), Cognition and second language instruction (pp. 3-32). Cambridge, UK: Cambridge University Press.

Schmidt, R., \& Frota, S. (1986). Developing basic conversational ability in a second language: A case study of an adult learner of Portuguese. In R. Day (Ed.), Talking to learn: Conversation in second language acquisition (pp. 237-326). Rowley, MA: Newbury House.

Seliger, H. W. (1975). Inductive method and deductive method in language teaching: A re- 
examination. International Review of Applied Linguistics in Language Teaching, 13(1-4), 1-18.

Shaffer, C. (1989). A comparison of inductive and deductive approaches to teaching foreign languages. Modern Language Journal, 73(4), 395-403.

Sharwood-Smith, M. (1988). Consciousness raising and the second language learner. In W. Rutherford \& M. Sharwood-Smith (Eds.), Grammar and second language teaching (pp. 51-60). New York, NY: Newbury House.

Sharwood-Smith, M. (1993). Input enhancement in instructed SLA: Theoretical bases. Studies in Second Language Acquisition, 15(2), 165-179.

Takahashi, S. (2010). Assessing learnability in second language pragmatics. In A. Trosborg (Ed.), Pragmatics across languages and cultures (pp. 391-421). Berlin, Germany: Mouton de Gruyter.

Takahashi, T., \& Beebe, L. (1993). Cross-linguistic influence in the speech act of correction. In G. Kasper \& S. Blum-Kulka (Eds.), Interlanguage pragmatics (pp. 138-158). New York, NY: Oxford University Press.

Takimoto, M. (2006). The effects of explicit feedback on the development of pragmatic proficiency. Language Teaching Research, 10(4), 393-417.

Takimoto, M. (2008). The effects of deductive and inductive instruction on the development of language learners' pragmatic competence. Modern Language Journal, 92(3), 369-386.

Takimoto, M. (2009). The effects of input-based tasks on the development of learners' pragmatic proficiency. Applied Linguistics, 30(1), 1-25.

Tanaka, K. (1997). Developing pragmatic competence: A learners-as-researchers approach. TESOL Journal, 6(3), 14-18.

Tateyama, Y. (2001). Explicit and implicit teaching of pragmatic routines: Japanese sumimasen. In K. Rose \& G. Kasper (Eds.), Pragmatics in language teaching (pp. 200-222). Cambridge, UK: Cambridge University Press.

Tateyama, Y., Kasper, G., Mui, L. P., Tay, H., \& Thananart, O. (1997). Explicit and implicit teaching of pragmatic routines. In L. F. Bouton (Ed.), Pragmatics and language learning (Vol. 8, pp. 163-177). Urbana-Champaign, IL: University of Illinois.

Tomlinson, B. (1994). Pragmatic awareness activities. Language Awareness, 3(3-4), 119-129.

Trosborg, A. (2003). The teaching of business pragmatics. In A. Martínez-Flor, E. Usó-Juan, \& A. Fernández-Guerra (Eds.), Pragmatic competence and foreign language teaching (pp. 247-281). Castelló de la Plana, Spain: Publicacions de la Universitat Jaume I.

Trosborg, A., \& Shaw, P. (1998). "Sorry does not pay my bills": The handling of complaints in everyday interaction/cross-cultural business interaction. Hermes, Journal of Linguistics, 21, 67-94.

Trosborg, A., \& Shaw, P. (2008). Deductive and inductive methods in the teaching of business pragmatics: Not an "either/or"! In R. Geluykens \& B. Kraft (Eds.), Institutional discourse in cross-cultural contexts (pp. 193-220). Munich, Germany: Lincom Europa.

Vogel, S. P., \& Engelhard, G., Jr. (2011). Using Rasch measurement theory to examine two instructional approaches for teaching and learning of French grammar. Journal of Educational Research, 104(4), 267-282.

Vogel, S., Herron, C., Cole, S. P., \& York, H. (2011). Effectiveness of a guided inductive versus a deductive approach on the learning of grammar in the intermediate-level college French classroom. Foreign Language Annals, 44(2), 353-380.

Vygotsky, L. S. (1978). Mind in society: The development of higher psychological processes. Cambridge, MA: Harvard University Press.

Walkinshaw, I. (2007). Power and disagreement: Insights into Japanese learners of English. RELC Journal, 38(3), 278-301.

Yates, L. (2010). Speech act performance in workplace settings. In A. Martínez-Flor \& E. Usó-Juan (Eds.), Speech act performance: Theoretical, empirical and methodological issues (pp. 109-126). Amsterdam, Netherlands: John Benjamins. 